Article

\title{
The Effects of Davallic Acid from Davallia divaricata Blume on Apoptosis Induction in A549 Lung Cancer Cells
}

\author{
An-Sheng Cheng ${ }^{1}$, We-Chang Chang ${ }^{2}$, Yu-Hsiang Cheng ${ }^{3}$, Kai-Yu Chen ${ }^{4}$, Kai-Hsien Chen ${ }^{1}$ \\ and Tsu-Liang Chang ${ }^{1, *}$
}

1 Department of Horticulture and Landscape Architecture, National Taiwan University,

1 Roosevelt Road Section 4, Taipei 10617, Taiwan; E-Mails: d99628009@ntu.edu.tw (A.-S.C.); kaic@sinetics.com.tw (K.-H.C.)

2 Institute of Food Science and Technology, National Taiwan University, 59 Roosevelt Road Section 4, Taipei 10617, Taiwan; E-Mail: d99641001@ntu.edu.tw

3 Department of Science, University of Auckland, 23 Symonds Street, Auckland 1142, New Zealand; E-Mail: yche556@aucklanduni.ac.nz

4 Department of Life Sciences, National Cheng Kung University, 1 University Road, Tainan 70101, Taiwan; E-Mail: C5497105@email.ncku.edu.tw

* Author to whom correspondence should be addressed; E-Mail: ghouse@ntu.edu.tw; Tel.: +886-2-3366-4875; Fax: +886-2-2366-1441.

Received: 29 September 2012; in revised form: 27 October 2012 / Accepted: 29 October 2012 / Published: 1 November 2012

\begin{abstract}
Traditional or folk medicinal herbs continue to be prescribed in the treatment of various diseases and conditions in many cultures. Recent scientific efforts have focused on the potential roles of extracts of traditional herbs as alternative and complementary medications for cancer treatment. In Taiwan, Davallia divaricata Blume has been traditionally employed in folk medicine for therapy of lung cancer, davallic acid being the major active compound of $D$. divaricata Blume. In this study, we investigated the inhibitory activity of davallic acid on the proliferation of A549 lung cancer cells. Davallic acid was extracted from $D$. divaricata Blume, and its effects on cell viability, cell cycle distribution, ROS level, and apoptotic protein expression in A549 cells were determined. Davallic acid significantly induced reactive oxygen species (ROS) generation as well as caspase-3, -8, and -9 activation, thereby repressing A549 cell growth and elevating apoptotic activity. Since lung cancer has a high incidence of recurrence, these results indicate that davallic acid may have the potential to be a natural anti-lung cancer compound, and may provide a basis for further study of its use in combating cancer.
\end{abstract}


Keywords: Davallia divaricata Blume; davallic acid; lung cancer; apoptotic activity

\section{Introduction}

Lung cancer is the cause of approximately $20 \%$ of tumor-related deaths worldwide; in Taiwan, it is the first- and the second-most lethal cancer type for females and males, respectively. Approximately $70 \%$ of lung cancer patients die from metastasis. Cancer metastasis refers to the spread of cancer cells from the primary neoplasm to distant sites and the growth of secondary tumors at sites distant from the primary tumor [1].

Davallia divaricata Blume is a fern perennial (genus Davallia, family Davalliaceae). It is a folk remedy "Gusuibu" known for its use in traditional Chinese medicine [2]. The dry rhizomes display many biological applications with therapeutic effects against diseases such as musculoskeletal traumatic disorders [3], rheumatoid arthritis and osteoporosis [4]. Chemical examination of this plant have resulted in the isolation of a series of compounds, including davallic acid $[5,6]$, $(+)$-catechin-3-O- $\beta$-D-allopyranoside, $(-)$ epicatechin-3- $O-\beta$-D-allopyranoside, procyanidins B-1 and B-2, trimeric procyanidin [7], $\beta$-carboxymethyl-(-)-epicatechin, and epiafzelechin- $(4 \beta \rightarrow 6)$-epicatechin$(4 \beta \rightarrow 8)$-epicatechin- $(4 \beta \rightarrow 6)$-epicatechin [8]. The structure of davallic acid was determined in 1965 [6]. Since then, phytochemical studies have been conducted on the active constituents of these rhizomes however analytical tests of the activities of davallic acid have not been reported.

Traditional or folk medicinal herbs continue to be prescribed in the treatment of various diseases and conditions in many cultures. In Taiwan, D. divaricata Blume has been employed traditionally for the therapy of lung cancer in folk medicine although its mechanism remains unknown; moreover, its efficacy in combating cancer also remains unverified. Davallic acid was identified as a major active compound of D. divaricata Blume and its structure was certified by Lin et al. [6]. In the present study, we evaluated the capacity of davallic acid to inhibit lung cancer cell growth. Using large amounts of davallic acid purified from $D$. divaricata Blume, we examined the bioactivity of davallic acid by investigating the anti-lung cancer efficacy of davallic acid and it mechanism of action.

Some phytochemicals arrest the cell cycle in cancer cells by altering signal transduction pathways and via the induction of apoptosis through the generation of reactive oxygen species (ROS); ensuing cell death is accompanied by the activation of certain stress kinases [9]. Different caspases mediate the two apoptotic signaling pathways. Initiation of the Fas signaling pathway by either Fas/death receptors or tumor necrosis factor (TNF)-receptor causes recruitment of Fas-associated protein with death domain (FADD) via interactions between the death domains of Fas and FADD. Caspase- 8 is activated by the binding of procaspase- 8 to the Fas/FADD complex, in turn activating caspase- 3 and inducing apoptosis. The second apoptotic pathway is regulated by the mitochondrial release of cytochrome $c$, resulting in the activation of caspase-9 and caspase-3 [10]. 


\section{Results}

\subsection{Structure Elucidation of Davallic Acid}

The EtOH extracts of dry D. divaricata Blume rhizomes were successively partitioned which resulted in isolation of a crystalline white powder, m.p. $283-284{ }^{\circ} \mathrm{C} ;[\alpha]_{D}^{24}:+3.6^{\circ}\left(c=0.87, \mathrm{CHCl}_{3}\right)$. The LC-MS/MS analysis revealed a major peak at $m / z 439.3\left(\mathrm{M}-\mathrm{H}^{-}\right)$with very little fragmentation that confirmed the molecular formula to be $\mathrm{C}_{30} \mathrm{H}_{48} \mathrm{O}_{2}$ (MW 440). Further MS/MS analysis yielded very little fragment ions, which agrees with the triterpene compound nature. The compound was therefore identified as davallic acid (Figure 1) [11] based on its ${ }^{1} \mathrm{H}$ - and ${ }^{13} \mathrm{C}-\mathrm{NMR}$ spectrum (Table 1) along with data comparisons with literature data.

Figure 1. The structure of davallic acid.

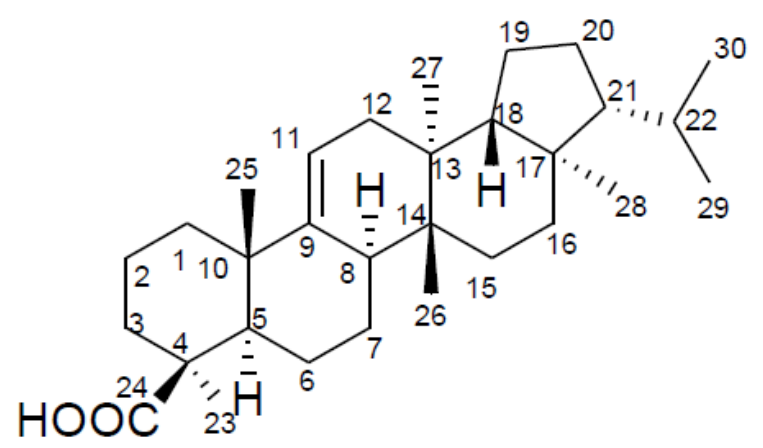

Table 1. ${ }^{1} \mathrm{H}$ and ${ }^{13} \mathrm{C}$-NMR spectroscopic data for davallic acid.

\begin{tabular}{ccc}
\hline Position & $\boldsymbol{\delta}_{\mathbf{H}}(\boldsymbol{J}$ in $\mathbf{H z})$ & $\boldsymbol{\delta}_{\mathbf{C}}$ \\
\hline 1 & & 41.8 \\
2 & & 19.5 \\
3 & & 42.7 \\
4 & & 35.8 \\
5 & & 46.9 \\
6 & & 18.2 \\
7 & & 19.8 \\
8 & & 39.4 \\
9 & $5.36(1 \mathrm{H}, \mathrm{m})$ & 149.7 \\
10 & 38.0 \\
11 & & 116.7 \\
12 & 36.5 \\
13 & & 37.5 \\
14 & & 38.3 \\
15 & & 28.1 \\
16 & & 36.4 \\
17 & & 44.3 \\
18 & & 51.7 \\
19 & & 20.2 \\
20 & & 28.0 \\
\hline
\end{tabular}


Table 1. Cont.

\begin{tabular}{ccc}
\hline Position & $\boldsymbol{\delta}_{\mathbf{H}}(\boldsymbol{J}$ in $\mathbf{~ H z})$ & $\boldsymbol{\delta}_{\mathbf{C}}$ \\
\hline 21 & & 59.4 \\
22 & & 29.0 \\
23 & $1.25(3 \mathrm{H}, \mathrm{s})$ & 30.5 \\
24 & & 183.9 \\
25 & $1.02(3 \mathrm{H}, \mathrm{s})$ & 23.1 \\
26 & $0.75(3 \mathrm{H}, \mathrm{s})$ & 15.4 \\
27 & $0.83(3 \mathrm{H}, \mathrm{s})$ & 15.3 \\
28 & $0.78(3 \mathrm{H}, \mathrm{s})$ & 13.7 \\
29 & $0.85(3 \mathrm{H}, \mathrm{d}, J=6.7)$ & 21.9 \\
30 & $0.90(3 \mathrm{H}, \mathrm{d}, J=6.7)$ & 22.7 \\
\hline
\end{tabular}

\subsection{The Effect of Davallic Acid on A549 Viability}

The effect of davallic acid in inhibiting A549 cell viability is shown in Figure 2. The results indicate that davallic acid $(5,10$, and $20 \mu \mathrm{M})$ decreased A549 cell viability within 12 and $24 \mathrm{~h}$ of treatment to $73 \%$ and $57 \%$ with $20 \mu \mathrm{M}$ davallic acid, respectively. These results suggest that davallic acid exhibits potential apoptotic induction, thereby repressing cell proliferation. Moreover, we evaluated the apoptosis index of A549 cells treated with davallic acid.

Figure 2. Representative cell viability of A549 cells treated by davallic acid at various concentrations for $12 \mathrm{~h}$ and $24 \mathrm{~h}$, respectively. Results are expressed as mean $\pm \mathrm{SD}(\mathrm{n}=3)$. $* p<0.05$ was compared with the $0 \mu \mathrm{M}$ concentration.

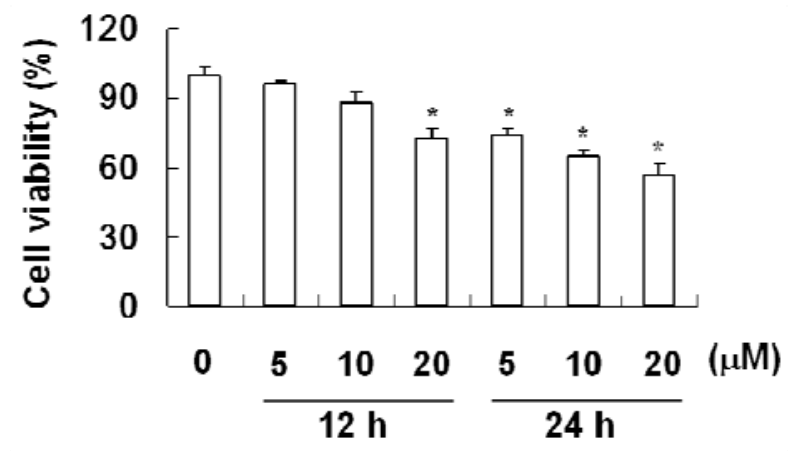

\subsection{The Effect of Davallic Acid on Cell Cycle}

The sub- $\mathrm{G}_{1}$ phase, in which DNA fragmentation peaks, represents apoptosis generation [12-14]. The sub- $\mathrm{G}_{1}$ phase was significantly increased by $34 \%$ and $42 \%$ following treatment with 10 and $20 \mu \mathrm{M}$ davallic acid for $24 \mathrm{~h}$, respectively, as compared to the control group (Figure 3).

Cells were stained with DCFH-DA to examine the production of ROS in the A549 cells, and DCF fluorescence was measured by a flow cytometer. As shown in Figure 4, both 10 and $20 \mu \mathrm{M}$ davallic acid significantly increased ROS levels after 12 and $24 \mathrm{~h}$ of treatment as compared to the control group. These results revealed that davallic acid induced apoptosis and suppressed cell viability by promoting the ROS levels, activating apoptotic signals in A549 cells. Therefore, we further investigated the apoptotic pathway induced by davallic acid. 
Figure 3. Effects of davallic acid on A549 apoptosis (sub G1 peak) after treatment for $12 \mathrm{~h}$ and $24 \mathrm{~h}$, respectively. (A) control; (B) $10 \mu \mathrm{M}$ treatment for $12 \mathrm{~h}$; (C) $20 \mu \mathrm{M}$ treatment for $12 \mathrm{~h}$; (D) $10 \mu \mathrm{M}$ treatment for $24 \mathrm{~h}$; (E) and $20 \mu \mathrm{M}$ treatment for $24 \mathrm{~h}$.

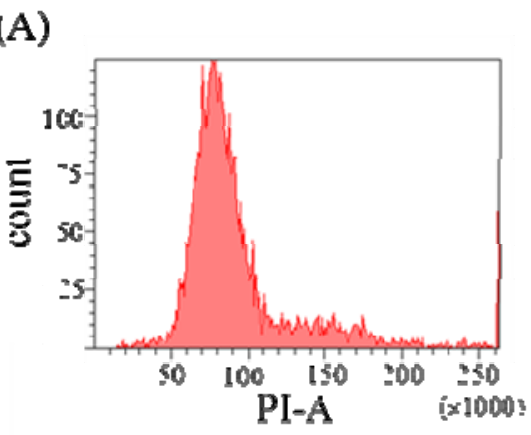

(B)

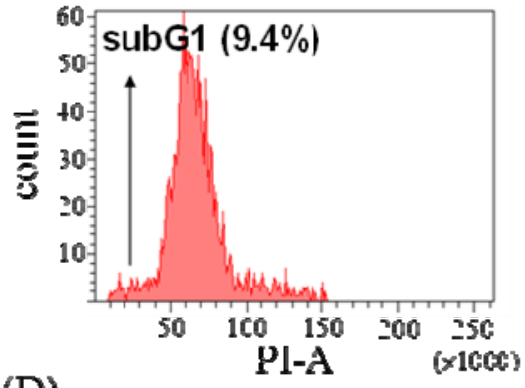

(D)

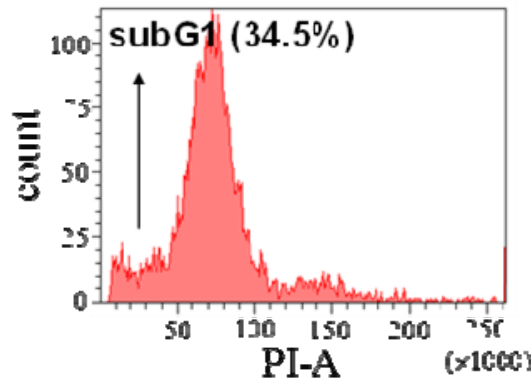

(C)

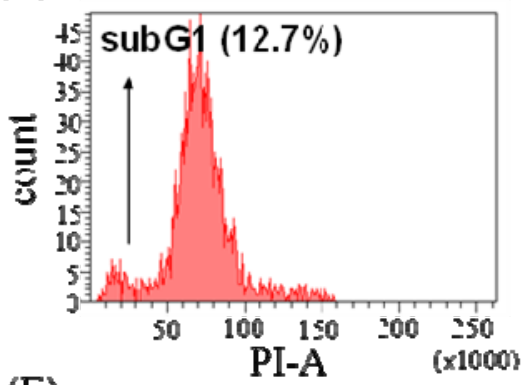

(E)

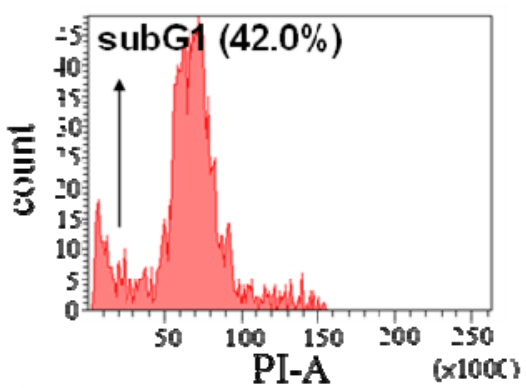

Figure 4. ROS production of A549 cells treating with davallic acid at various concentrations for $12 \mathrm{~h}$ and $24 \mathrm{~h}$, respectively. Results are expressed as mean $\pm \mathrm{SD}(\mathrm{n}=3)$. $* p<0.05$ and $* * p<0.01$ were compared with the first line that $0 \mu \mathrm{M}$ concentration.

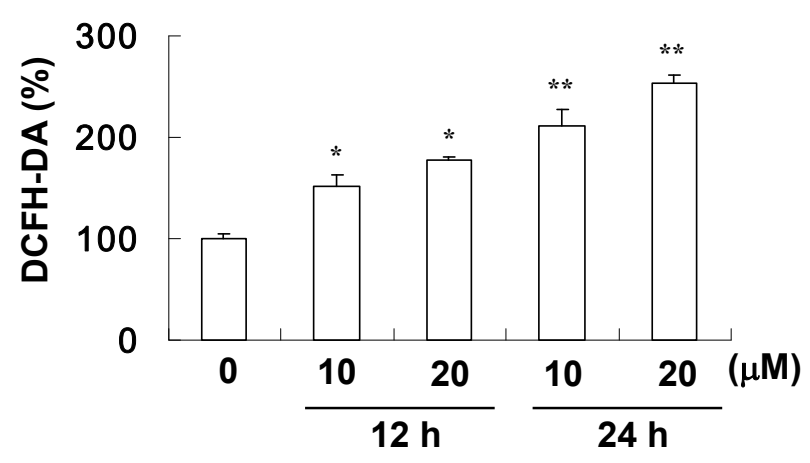

\subsection{The Effect of Davallic Acid on Bax and Bcl-2 Proteins in A549 Cell}

We observed that 10 and $20 \mu \mathrm{M}$ davallic acid significantly increased cytosolic Bax levels in A549 cells treated for $24 \mathrm{~h}$ (Figure 5A). Furthermore, these treatments potentially suppressed a decrease in cytosolic Bcl-2 in A549 cells (Figure 5B). Moreover, we noted a significant increase in cytosolic cytochrome $c$ in A549 cells treated with davallic acid $(10$ and $20 \mu \mathrm{M})$ for $24 \mathrm{~h}$ as compared to the 
control group (Figure 5C). These results suggest that davallic acid induced mitochondrial membrane damage and membrane potential loss, enhancing Bax expression and inhibiting Bcl-2 expression, subsequently leading to cytochrome $c$ release.

Figure 5. Bax and Bcl-2 expression of A549 cells treating with davallic acid at various concentrations for $12 \mathrm{~h}$ and $24 \mathrm{~h}$, respectively. (A) Bax expression; (B) Bcl-2 expression; and (C) Cytosolic cytochrome C. Results are expressed as mean $\pm \mathrm{SD}(\mathrm{n}=3)$. ${ }^{*} p<0.05$ was compared with the first line that $0 \mu \mathrm{M}$ concentration.

(A)

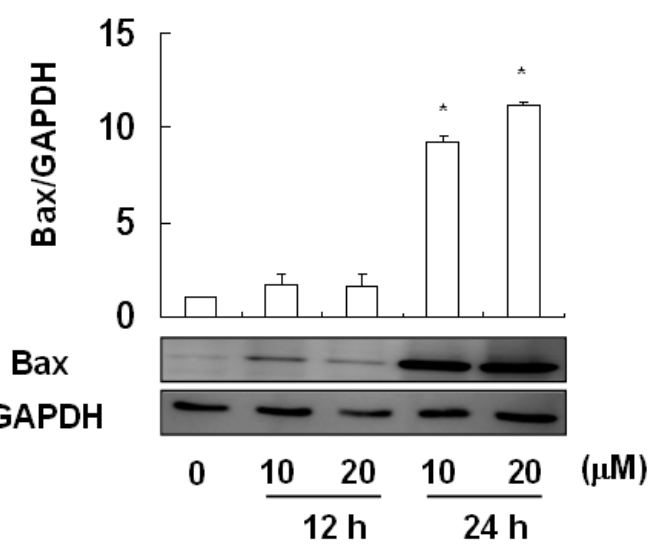

(B)

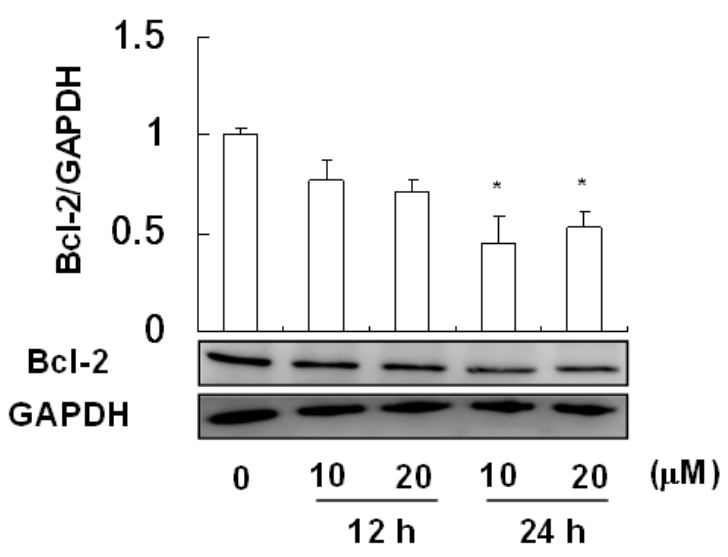

(C)

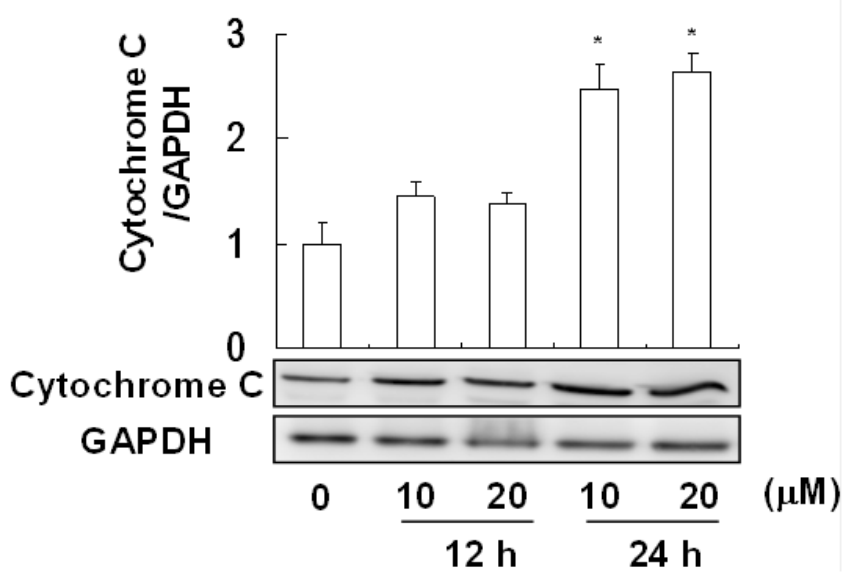

\subsection{The Effect of Davallic Acid on Caspase Activity}

Apoptosis is regulated by two main pathways: The TNF- $\alpha$ receptor pathway and the mitochondrial pathway, both of which involve the activation of caspase-3. Caspase-8 and caspase-9 are activators/initiators of the TNF- $\alpha$ receptor and mitochondrial pathways, respectively. The activities of caspase-3, caspase-8, and caspase-9 in A549 cells treated with davallic acid are shown in Figure 6A-C, respectively. Davallic acid $(10$ and $20 \mu \mathrm{M})$ treatment for $24 \mathrm{~h}$ significantly promoted the activation of caspase-3, caspase-8, and caspase-9 in the A549 cells as compared to that in the control group. 
Figure 6. Caspases expression of A549 cells treating with davallic acid at various concentrations for $12 \mathrm{~h}$ and $24 \mathrm{~h}$, respectively. (A) Caspase-3; (B) caspase-8; (C) and caspase-9. Results are expressed as mean $\pm \mathrm{SD}(\mathrm{n}=3)$. ${ }^{*} p<0.05$ was compared with the first line that $0 \mu \mathrm{M}$ concentration.

(A)

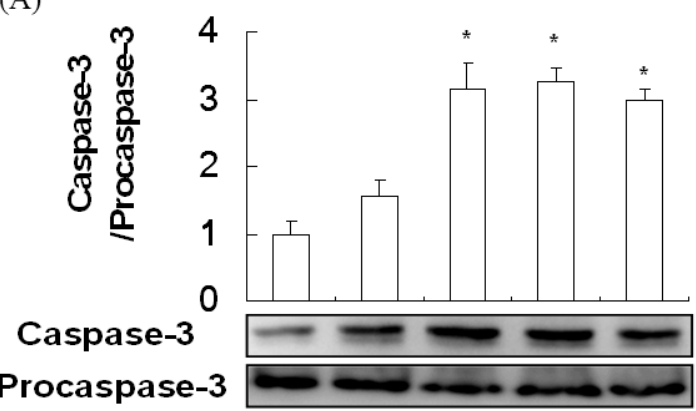

$0 \quad \frac{1020}{12 \mathrm{~h}} \quad \frac{1020}{24 \mathrm{~h}} \quad(\mu \mathrm{M})$

(C)
(B)

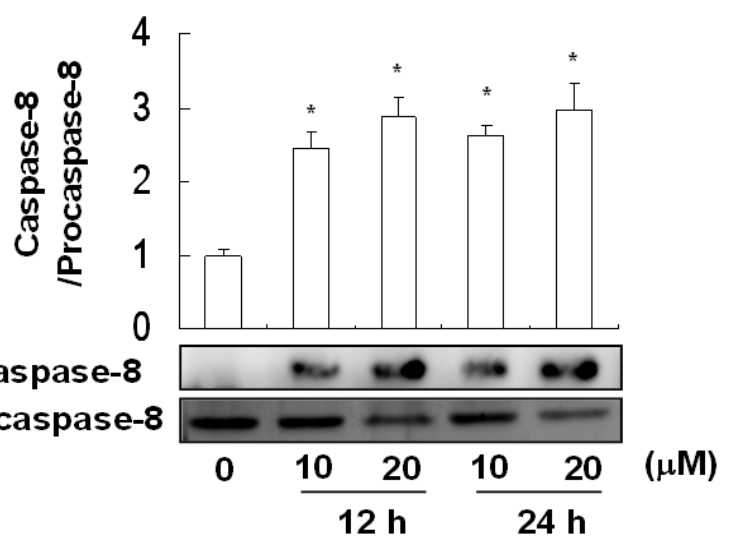

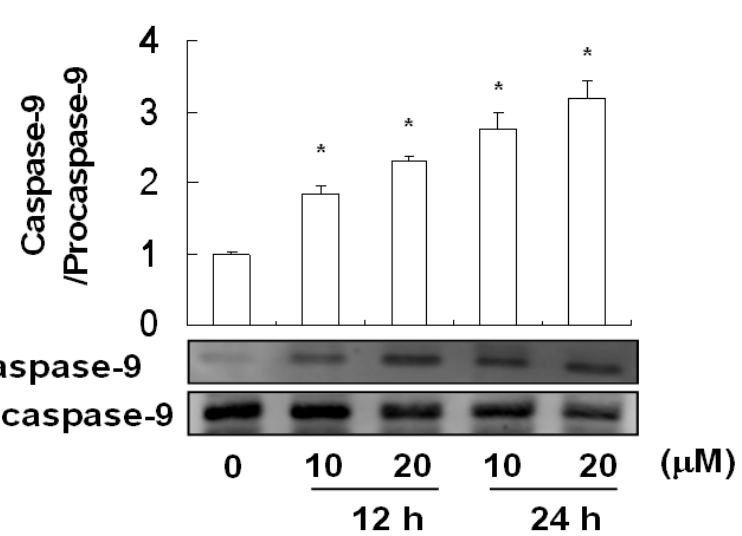

\section{Discussion}

Several lines of evidence demonstrate that excessive oxidative stress caused by ROS and reactive nitrogen species (RNS) can promote disease progression via the oxidation of biomolecules such as DNA, lipids, and proteins [15,16]. High levels of ROS in the mitochondria can result in free radicals attacking membrane phospholipids, which precedes mitochondrial membrane depolarization. Mitochondrial depolarization, which is considered an irreversible step in apoptosis, triggers a cascade of caspases $[17,18]$.

The Bcl-2 family of proteins includes proteins that can either inhibit (e.g., Bcl-2, and Bcl-xL) or induce (e.g., Bax, Bak, and Bad) apoptosis. Bcl-2 is an antiapoptotic protein that is predominantly present in mitochondria and prevents apoptosis by suppressing oxyradical-mediated membrane damage and stabilizing mitochondrial membrane potential [19,20]. The proapoptotic protein Bax regulates the mitochondrial pathway by triggering the release of apoptotic factors such as cytochrome $c$ from mitochondria following apoptotic signals [21]. Bcl-2 is known as an upstream effector molecule in the apoptotic pathway, and has been identified as a potent suppressor of apoptosis [22,23].

In addition, Bcl-2 promotes cell survival by preserving the integrity of the external mitochondrial membrane, which prevents the release of cytochrome $c$ from mitochondria, thus preventing cell 
death $[20,24]$. Bax is a $21-\mathrm{kDa}$ protein that promotes mitochondrial membrane permeability; it has been demonstrated to accelerate apoptotic cell death $[25,26]$.

In recent years, natural food products have received increasing attention because of their potential roles in the prevention and/or intervention of cancers, including lung cancer. Oxidative damage to cellular macromolecules can arise through the overproduction of ROS and faulty antioxidant and/or DNA repair mechanisms that result in cancer [27]. Phytochemicals offer significant protective benefits against oxidative damage [14]. The antiproliferative activities of polyphenols such as delphinidin, cyanidin, peonidin, petunidin, and malvidin have been previously reported [28]. Davallic acid, as shown in the present study, suppressed cell viability and induced apoptosis in the A549 cancer cells via increased ROS expression, enhanced release of cytochrome $c$, and induction of caspase-3, caspase-8, and caspase-9 expression.

Six species of botanical rhizoma derivatives of Gusuibu have been found in Taiwan: Drynaria fortune (Kunze) J. Smith, Pseudodrynaria coronans (Wallich) Ching (both from Polypodiaceae), Davallia divaricata Blume, Davallia mariesii Moore ex Bak, Davallia solida (Forst) Swartz, and Humata griffithiana (Hooker) [2]. These six species have found uses in modern and traditional medicinal practices, including treatments for body discomfort, inflammation, cancer, ageing, blood stasis, and bone injuries [2]. Davallic acid is the major active compound of Gusuibu. Although the molecular structure of davallic acid was determined in 1965 [6], the bioactivity is yet be reported to date. A few studies have suggested that Gusuibu extract has cancer preventative properties [6,29]. While other studies have found that Gusuibu extract may inhibit A549 lung cancer cells invasion and migration. The study also reports that Gusuibu extract may restrain the tumor growth and migration in vivo [30]. Therefore, the davallic acid derivatives of Gusuibu may have applications as preventative agents to fight cancer which would indicate this compound merits further studies, and we feel the necessity to study the echanism of davallic acid bioactivity to determine its effectiveness.

\section{Experimental}

\subsection{General}

${ }^{1} \mathrm{H}$ - and ${ }^{13} \mathrm{C}$ NMR spectra were obtained on a Bruker AM-500 spectrometer in $\mathrm{CDC}_{3}$ solution, using the corresponding solvent peak as the internal standard. Optical rotation was measured on a Jasco DIP-1020 digital polarimeter. Column chromatography was carried out with Sephadex LH-20 (25-100 $\mu \mathrm{M}$, Pharmacia Fine Chemicals). TLC was conducted on silica gel plates (60 F-254, Merck) and $10 \%$ sulfuric acid solution was used as a visualizing agent following heating. Propidium iodide (PI), sodium dodecyl sulfate (SDS), Triton X-100, and trypsin were purchased from Sigma Chemical Co. (St. Louis, MO, USA). Fetal bovine serum (FBS) was purchased from Life Technologies (Auckland, New Zealand). Dimethyl sulfoxide (DMSO) was purchased from Wako Pure Chemical Industries (Saitama, Japan). Ham's F-12, sodium bicarbonate, hydrocortisone, penicillin, and streptomycin were purchased from HyClone Laboratories (Logan, UT, USA). 


\subsection{Plant Material and Isolation}

The plant, D. divaricata Blume, collected in Taipei, Taiwan, in July 2010 was kindly supplied for this study by The Forestry Bureau of Taiwan. The sliced rhizomes were used for the extraction of davallic acid. The rhizomes $(25 \mathrm{~kg})$ were extracted with $80 \% \mathrm{EtOH}(10 \mathrm{~L})$ three times at room temperature. After evaporating the solvents under vacuum at $40{ }^{\circ} \mathrm{C}$, a residue was obtained. This residue was dissolved in $\mathrm{H}_{2} \mathrm{O}$ and then extracted successively with hexane, ethyl acetate, and $n-\mathrm{BuOH}$. The hexane extract (62 g) was fractionated on a Sephadex LH-20 column and eluted with EtOH to yield fractions A-D. The fraction C (5 g) was recrystallized from hexane/acetone. Finally, the sediment was washed with EtOH to give $1.5 \mathrm{~g}$ of davallic acid. The structure of the isolated compound was elucidated using Bruker Avance DRX 500 NMR and Agilent 1200/6460 LC-MS-MS for mass spectra confirmation.

\subsection{Cell Culture}

A549 lung cancer cells were obtained from the Bioresource Collection and Research Center (BCRC) in Taiwan (Hsinchu, Taiwan), and cultured on F12-K medium supplemented with 10\% heat-inactivated FBS and antibiotics (100 unit $\mathrm{mL}^{-1}$ penicillin and $100 \mu \mathrm{g} \mathrm{mL} \mathrm{m}^{-1}$ streptomycin). Cells were cultured at $37{ }^{\circ} \mathrm{C}$ in a humidified atmosphere of $5 \% \mathrm{CO}_{2}$.

\subsection{Cell Viability}

A549 cells were seeded into 48 -well plates in $1 \mathrm{~mL}$ of F-12K medium. The cells were treated with different concentrations of samples. At the end of incubation, the cells were washed with PBS, and the supernatants were exchanged with $1 \mathrm{~mL}$ of medium and MTT $\left(0.5 \mathrm{mg} \mathrm{mL}^{-1}\right)$ to react for $2 \mathrm{~h}$ at $37^{\circ} \mathrm{C}$. After washing with PBS, MTT tetrazolium was dissolved with DMSO and measured at $570 \mathrm{~nm}$ [10].

\subsection{Assay for ROS Level}

A549 cells $\left(2 \times 10^{6}\right.$ cells/per well $)$ were treated with various concentrations of davallic acid for different durations of time $(12 \mathrm{~h}$ and $24 \mathrm{~h})$. The collected cells were suspended in $500 \mu \mathrm{L}$ of PBS, mixed with $10 \mu \mathrm{M} 2^{\prime}, 7^{\prime}$-dichlorfluorescein-diacetate (DCFH-DA) and incubated for $20 \mathrm{~min}$ at $37^{\circ} \mathrm{C}$. Afterwards, the cells were washed thrice to remove DCFH-DA. The cell pellet was then mixed with $500 \mu \mathrm{L}$ of PBS and the ROS level was assayed by flow cytometry.

\subsection{Cell Cycle Distribution}

After exposure to davallic acid, the medium was aspirated and adherent cells were harvested and centrifuged at $300 \times \mathrm{g}$ for $5 \mathrm{~min}$. Cells were washed with PBS, fixed with ice-cold ethanol at $-20{ }^{\circ} \mathrm{C}$ overnight and then stained with PI at room temperature for $30 \mathrm{~min}$. The cell cycle distribution was analyzed by flow cytometry using a FACScan-LSR flow cytometer equipped with CellQuest software (BD Biosciences, San Jose, CA, USA) [10]. 


\subsection{Immunoblot Analysis}

A549 cells were lysed in ice-cold lysis buffer containing $20 \mathrm{mM}$ of Tris- $\mathrm{HCl}(\mathrm{pH} 7.4), 1 \%$ of Triton $\mathrm{X}-100,0.1 \%$ of SDS, $2 \mathrm{mM}$ of EDTA, $10 \mathrm{mM}$ of NaF, $1 \mathrm{mM}$ of phenylmethylsulfonyl fluoride (PMSF), $500 \mu \mathrm{M}$ of sodium-vanadate, and $10 \mu \mathrm{g} / \mathrm{mL}$ of aprotinin overnight. Then, cell lysates were sonicated with ice cooling (four times each $15 \mathrm{~s}$ ) and centrifuged $(12,000 \times \mathrm{g}, 10 \mathrm{~min}$ ) to recover the supernatant. The supernatant was taken as the cell extract. The protein concentration in the cell extract was determined using a Bio-Rad protein assay kit. The samples were subjected to $10 \%$ sodium dodecyl sulfate-polyacrylamide gel electrophoresis (SDS-PAGE). The protein spots were electrotransferred to a polyvinylidene difluoride (PVDF) membrane. The membrane was incubated with a block buffer for $1 \mathrm{~h}$, washed with PBS containing 0.05\% Tween-20 (PBST) three times, and then probed with 1:5,000 diluted solution of anti-caspase-3, anti-procaspase-3, anti-caspase-8, anti-procaspase-8, anti-caspase-9, anti-procaspase-9, 1:2,000 diluted solution of anti-cytochrome, anti-Bcl-2, anti-Bax, and anti-GAPDH $(1: 5,000)$ (Cell Signaling Technology, Beverly, MA, USA) overnight at $4{ }^{\circ} \mathrm{C}$. The membrane was washed three times each for $5 \mathrm{~min}$ in PBST, shaken in a solution of HRP-linked anti-rabbit IgG secondary antibody, and washed three more times each for $5 \mathrm{~min}$ in PBST. The expressions of proteins were detected using enhanced chemiluminescent (ECL) reagent (Millipore, Billerica, MA, USA).

\subsection{Statistical Analysis}

Data were expressed as mean \pm standard deviation (SD). Statistical significance was determined by one-way analysis of variance (ANOVA) using the general linear model procedure of SPSS Version 17.0. [31], followed by ANOVA with Duncan's test. All comparisons were performed relative to controls, and significant differences are indicated.

\section{Conclusions}

In conclusion, in this study we affirmed that davallic acid obtained from $D$. divaricata Blume induced cell death in lung A549 cancer cells, playing an important role in apoptosis induction via caspase-3, caspase-8, and caspase-9 activation. We therefore consider davallic acid may have potential as a natural anti-lung cancer compound, warranting further study.

\section{Acknowledgments}

The authors wish to thank Bih-Yuh Lin for providing language help.

\section{References and Notes}

1. Yang, Y.T.; Weng, C.J.; Ho, C.T.; Yen, G.C. Resveratrol analog-3,5,4'-trimethoxy-trans-stilbene inhibits invasion of human lung adenocarcinoma cells by suppressing the MAPK pathway and decreasing matrix metalloproteinase-2 expression. Mol. Nutr. Food. Res. 2009, 53, 407-416.

2. Chang, H.C.; Huang, G.J.; Agrawal, D.C.; Kuo, C.L.; Wu, C.R.; Tsay, H.S. Antioxidant activities and polyphenol contents of six folk medicinal ferns used as "Gusuibu". Bot. Stud. 2007, 48, 397-406. 
3. Sun, J.S.; Dong, G.C.; Lin, C.Y.; Sheu, S.Y.; Lin, F.H.; Chen, L.T.; Chang, W.H.; Wang, Y.J. The effect of Gu-Sui-Bu (Drynaria fortunei J. Sm) immobilized modified calcium hydrogenphosphate on bone cell activities. Biomaterials 2003, 24, 873-882.

4. Ko, Y.J.; Wu, J.B.; Ho, H.Y.; Lin, W.C. Antiosteoporotic activity of Davallia formosana. J. Ethnopharmacol. 2012, 139, 558-565.

5. Nakanishi, K.; Lin, Y.Y.; Kakisawa, H.; Hsu, H.Y.; Hsiu, H.C. Davallic acid, a triterpene with a novel akeleton. Tetrahedron Lett. 1963, 22, 1451-1457.

6. Lin, Y.Y.; Kakisawa, H.; Shiobara, Y.; Nakanishi, K. The structure of Davallic acid. Chem. Pharm. Bull. 1965, 13, 986-995.

7. Hwang, T.H.; Kashiwada, Y.; Nonaka, G.I.; Nishioka, I. Flavan-3-ol and proanthocyanidin allosides from Davallia divaricata. Phytochemistry 1989, 28, 891-896.

8. Hwang, T.H.; Kashiwada, Y.; Nonaka, G.I.; Nishioka, I. 4-Carboxymethyl flavan-3-ols and procyanidins from Davallia divaricata. Phytochemistry 1990, 29, 279-282.

9. Umansky, V.; Ushmorov, A.; Ratter, F.; Chlichlia, K.; Bucur, M.; Lichtenauer, A.; Rocha, M. Nitric oxide-mediated apoptosis in human breast cancer cells requires changes in mitochondrial functions and is independent of CD95 (APO-1/Fas). Int. J. Oncol. 2000, 16, 109-117.

10. Hsu, W.H.; Lee, B.H.; Pan, T.M. Red mold dioscorea-induced G2/M arrest and apoptosis in human oral cancer cells. J. Sci. Food Agric. 2010, 90, 2709-2715.

11. Ahmad, V.U.; Rahman, A.U. Handbook of Natural Products Data, Volume 2: Pentacyclic Ttriterpenoids; Elsevier: London, UK, 1994; p. 1365.

12. Shieh, D.F.; Chen, Y.Y.; Yen, M.H.; Chiang, L.C.; Lin, C.C. Emodin-induced apoptosis through p53-dependent pathway in human hepatoma cells. Life Sci. 2004, 74, 2279-2290.

13. Srinivas, G.; Anto, R.J.; Srinivas, P.; Vidhyalakshmi, S.; Senan, V.P.; Karunagaran, D. Emodin induces apoptosis of human cervical cancer cells through poly (ADP-ribose) polymerase cleavage and activation of caspase-9. Eur. J. Pharmacol. 2003, 473, 117-125.

14. $\mathrm{Hu}, \mathrm{R}$;; Kong, A.H.I. Activation of MAP kinases, apoptosis and nutrigenomics of gene expression elicited by dietary cancer-prevention compounds. Nutrition 2004, 20, 83-88.

15. Burke, A.; Fitzerald, G.A. Oxidative stress and smoking-induced vascular injury. Prog. Cardiovas. Dis. 2003, 46, 79-90.

16. Nakao, L.S.; Jwai, L.K.; Kalil, J.; Augusto, O. Radical production from free and peptide-bound methionine sulfoxide oxidation by peroxynitrite and hydrogen peroxide/iron(II). FEBS Lett. 2003, 547, 87-91.

17. Pelicano, H.; Feng, L.; Zhou, Y.; Carew, J.S.; Feng, L.; Bhalla, K.N.; Keating, M.J.; Huang, P. Inhibition of mitochondrial respiration: A novel strategy to enhance drug-induced apoptosis in human leukemia cells by a reactive oxygen species-mediated mechanism. J. Biol. Chem. 2003, 278, 37832-37839.

18. Stohs, S.J.; Baghi, D. Oxidative mechanisms in the toxicity of metal ions. Free Radic. Biol. Med. 1995, 18, 321-336.

19. Bruce-Keller, A.J.; Begley, J.G.; Fu, W.; Butterfield, D.A.; Bredesen, D.E.; Hutchins, J.B.; Hensley, K.; Mattson, M.P. Bcl-2 protects isolated plasma and mitochondrial membranes against lipid peroxidation induced by hydrogen peroxide and amyloid beta-peptide. J. Neurochem. 1998, 70, 31-39. 
20. Desagher, S.; Martinou, J.C. Mitochondria as the central control point of apoptosis. Trends Cell Biol. 2000, 10, 369-377.

21. Hsu, Y.T.; Wolter, K.G.; Youle, R.J. Cytosol-to-membrane redistribution of Bax and Bcl-X(L) during apoptosis. Proc. Natl. Acad. Sci. USA 1997, 94, 3668-3672.

22. Hockenbery, D.M.; Oltvai, Z.N.; Yin, X.M.; Milliman, C.L.; Korsmeyer, S.J. Bcl-2 functions in an antioxidant pathway to prevent apoptosis. Cell 1993, 75, 241-251.

23. Tsujimoto, Y.; Shimizu, S. Bcl-2 family: Life-or-death switch. FEBS Lett. 2000, 466, 6-10.

24. Kawakami, M.; Inagawa, R.; Hosokawa, T.; Saito, T.; Kurasaki, M. Mechanism of apoptosis induced by copper in PC12 cells. Food Chem. Toxicol. 2008, 46, 2157-2164.

25. Neuzil, J.; Wang, X.F.; Dong, L.F. Molecular mechanism of 'mitocan'-induced apoptosis in cancer cells epitomizes the multiple roles of reactive oxygen species and Bcl-2 family proteins. FEBS Lett. 2006, 580, 5125-5129.

26. Wolter, K.G.; Hsu, Y.T.; Smith, C.L.; Nechushtan, A.; Xi, X.G.; Youle, R.J. Movement of Bax from the cytosol to mitochondria during apoptosis. J. Cell Biol. 1997, 139, 1281-1292.

27. Klaunig, J.E.; Kamendulis, L.M.; Hocevar, B.A. Oxidative stress and oxidative damage in carcinogenesis. Toxicol. Pathol. 2010, 38, 96-109.

28. Jacob, J.K.; Hakimuddin, F.; Paliyath, G.; Fisher, H. Antioxidant and antiproliferative activity of polyphenols in novel high-polyphenol grape lines. Food Res. Int. 2008, 41, 419-428.

29. Cui, C.B.; Tezuka, Y.; Kikuchi, T.; Tamaoki, T.; Park, J.H. Constituents of fern, Davallia mariesii Moore. I. Isolution and structures of Davallialactone and a new flavanone glucuronide. Chem. Pharm. Bull. 1990, 38, 3218-3225.

30. Hsieh, Y.S. The study of Chinese medicinal herbs inhibitis cancer cell migration/invasion. Yearbook Chin. Med. Pharm. 2006, 24, 257-284.

31. SPSS, Version 17.0; a computer program used for survey authoring and deployment, data mining, text analytics, statistical analysis, and collaboration and deployment; SPSS Inc.: Chicago, IL, USA, 2008.

Sample Availability: Samples of the compounds are available from the authors.

(C) 2012 by the authors; licensee MDPI, Basel, Switzerland. This article is an open access article distributed under the terms and conditions of the Creative Commons Attribution license (http://creativecommons.org/licenses/by/3.0/). 